\title{
WSPÓŁPRACA SOJUSZU PÓLNOCNOATLANTYCKIEGO I UNII EUROPEJSKIEJ W OBLICZU OBECNYCH ORAZ PRZYSZEYCH ZAGROŻEŃ
}

Konflikt rosyjsko-ukraiński oraz ataki terrorystyczne w Europie i na świecie stały się wielkim sprawdzianem dla systemu bezpieczeństwa na obszarze Euroatlantyckim. Gruntowna zmiana sytuacji w Europie jednoznacznie unaoczniła przedawnienie Europejskiej oraz Natowskiej strategii bezpieczeństwa. Europa spotyka się dziś z wyzwaniami na bardzo szeroką skalę, które nie miały miejsca od czasu zakończenia Zimnej Wojny. Ostatni czas upłynął pod znakiem konfrontacji zbrojnej na Ukrainie, agresywnej polityki ze strony Rosji wobec państw byłego bloku wschodniego oraz ataków terrorystycznych przenoszących się powoli na stary kontynent. Bezprawna aneksja Krymu i rozpoczęcie walk we wschodniej części Ukrainy doprowadziły do niecodziennego wzrostu zagrożenia, na niespotykaną skalę od czasu upadku Muru Berlińskiego i demokratycznych przemian na terenie Europy. Dramatyczne wydarzenia z ostatniego okresu wpłynęły w głównej mierze na bezpośrednie zagrożenie Polski, która, z racji swojego geopolitycznego położenia, zaczęła odgrywać wiodącą rolę na forum europejskim w działaniach na rzecz zakończenia niebezpiecznego konfliktu.

Polska stała się także kluczowym państwem dla strategii NATO, która w odpowiedzi na działania Rosji, podjęła szereg kroków, mających na celu zapewnienie sojuszników z tej części Europy o trwałości zobowiązań dotyczących obrony kolektywnej w myśl Traktatu o NATO (Vademecum, 2007: 49). Materialną oznaką tych działań było wysłanie przez Sojusz, a zwłaszcza przez Stany Zjednoczone, dodatkowych samolotów i żołnierzy wojsk lądowych do Polski, państw bałtyckich i Rumunii. Wielokrotnie na polskich poligonach odbywały się wspólne ćwiczenia w celu zgrywania komponentów wojsk lądowych. W okresie letnim eskadra myśliwska USA ćwiczyła razem z polskimi pilotami loty w dużych ugrupowaniach bojowych z wykorzystaniem najnowszych trendów w taktyce lotniczej oraz realistycznych scenariuszy taktycznych. Ponadto od maja 2014 r. w Bazie Lotniczej w Malborku odbywa się rotacja eskadr NATO, które wspierają patrolowanie przestrzeni powietrznej nad państwami bałtyckimi w ramach misji Air-Policing (Gościnny, 2015). Wzmacnianie wschodniej flanki Sojuszu, poprzez rotacyjne ćwiczenia, będzie kontynuowane także w 2015 r., a większą dynamikę temu procesowi nada utworzenie sił natychmiastowego reagowania NATO. Wdrożenie nowej strategii NATO, która może być przełomem m.in. dla Polski, jest konieczne dla zbudowania nowej architektury bezpieczeństwa w Europie i na Świecie.

Jens Stoltenberg, obejmując stanowisko sekretarza generalnego NATO, w swoim expose przedstawił priorytety na najbliższe miesiące. Głównym założeniem będzie utrzymanie siły Sojuszu, zapewnienie stabilności w sąsiedztwie i wdrożenie strategii 
przyjętej podczas szczytu w Newport, co ma szczególne znaczenie dla bezpieczeństwa państw wschodniej flanki Sojuszu, w tym Polski. Kolejnym priorytetem na liście nowego szefa Sojuszu jest zacieśnienie współpracy NATO i Unii Europejskiej w ramach Wspólnej Polityki Bezpieczeństwa i Obrony i jej zasadnej komplementarności w Sojuszu Północnoatlantyckim (Blair, 2014). Jak podkreślił, zarówno Sojusz, jak i UE, zajmują się tym samym obszarem geograficznym, zaznaczając jednocześnie, że bliższa współpraca będzie miała szczególne znaczenie dla państw, które nie są członkami Unii. Warto przypomnieć, że z 28 państw NATO, 22 należą do Unii Europejskiej, która od lat podejmuje próby stworzenia wiarygodnej polityki bezpieczeństwa, co z pewnością w przyszłej perspektywie poprawi pozycję zarówno NATO, jak i UE, na arenie międzynarodowej.

\section{KRÓTKA HISTORIA EUROPEJSKIEJ OBRONY}

Europa skonfrontowana jest dziś z wyzwaniami w dawno niewystępującej skali. Narastający kryzys europejskiego bezpieczeństwa objawia się jednocześnie w wielu wymiarach: zewnętrznym i wewnętrznym, militarnym i pozamilitarnym oraz globalnym regionalnym (Koziej, 2014: 18). Stan obecny różni się diametralnie od realiów z 2003 r., gdy przyjmowano Europejską strategię bezpieczeństwa. Unia Europejska była wtedy w fazie ożywienia gospodarczego. $Z$ jednej strony niemal wspaniała atmosfera towarzyszyła sukcesowi wielkiego, zjednoczeniowego rozszerzenia Unii. Z drugiej strony, UE znajdowała się od końca 2001 r. w toku wypracowywania konstytucji europejskiej, a stricte - traktatu konstytucyjnego, który w zamierzeniu inspiratorów miał przynieść integracyjny przełom. Zamierzeniem było zmienić Unię Europejską w inną jakość integracji, a przy tym zunifikować istniejące i wyposażyć w nowe instytucje i instrumenty skutecznego działania na scenie międzynarodowej. Symbole międzynarodowe takie jak flaga, godło, hymn, dewiza, warunek o kolektywnej obronie i powołanie prezydenta UE miały stanowić nową tożsamość Unii Europejskiej w świecie. Przyjęcie wspólnej waluty oraz ustanowienie unijnego obywatelstwa również było wyrazem konsolidacji. Skoro to wszystko, to dlaczego nie wspólny potencjał obronny, w tym wspólna armia, które uczyniłyby Unię Europejską budzącym respekt uczestnikiem stosunków międzynarodowych, nie gorszym niż USA czy ChRL (Dyplomacja $c z y, 2009)$. Unia Europejska nie stworzyła wprawdzie europejskiej armii, ograniczając się do tworzenia tzw. grup bojowych pełniących półroczne dyżury (Zięba, 2012: 161-169). Z tego tytułu może warto się zastanowić nad wzmocnieniem potencjału militarnego Unii Europejskiej na wypadek możliwości zażegnania kryzysu bez udziału czołowego gracza NATO, jakim jest armia USA.

Jeśli państwa Unii Europejskiej chcą zachować wpływ na kształtowanie nowego porządku międzynarodowego, na sposób i kierunek jego ewolucji, muszą dysponować także twardymi argumentami potencjału. Silnie rozwiniętą i atrakcyjną (soft power) musi uzupełnić (hard power). Bez tego Europa, jej głos, nie będą poważnie brane pod uwagę przez resztę świata, a zwłaszcza przez nowe mocarstwa. UE nie powinna tego ignorować. Żadne z mocarstw starej Europy nie może się równać swym potencjałem militarnym z USA, ChRL czy Rosją. UE powinna zbudować porównywalny potencjał dla własnego bezpieczeństwa, dla stabilizowania sytuacji w otoczeniu, dla podejmo- 
wania operacji służących przywracaniu pokoju w innych częściach świata. Tylko razem we współpracy z Sojuszem Północnoatlantyckim jesteśmy w stanie zmierzyć się z współczesnymi zagrożeniami. Jedno z założeń Europejskiej Strategii Bezpieczeństwa mówi, że „Działając razem, Unia Europejska i Stany Zjednoczone mogą stanowić potężną siłę na rzecz dobra na świecie", a lepszy świat, na rzecz którego chciała działać, to świat „bardziej zjednoczony, bezpieczny i sprawiedliwy” (ESB, 2003: 12-14).

Powracając do przeszłości podczas szczytu NATO w Chicago do podstawowego traktatowego zadania Sojuszu, jakim jest kolektywna obrona, dodano dwa dodatkowe - opanowywanie kryzysów (w polskiej nomenklaturze określane, jako zarządzanie kryzysowe) oraz bezpieczeństwo oparte na współpracy - kooperatywne bezpieczeństwo (Pietrzak, 2012). Skoro, więc NATO służy przede wszystkim do wspólnej obrony terytorium państw członkowskich, to trzeba zadać sobie pytanie, co się stanie, jeżeli zagrożenie będzie dotyczyło państwa, które nie jest w NATO a jest członkiem Unii Europejskiej. Czy jesteśmy w stanie rozwiązać kryzys, używając środków militarnych bez użycia struktur sojuszu lub jego infrastruktury? Odpowiedź na to pytanie można znaleźć, powracając do byłej wojny w Jugosławii. Gdy zawiodły dyplomatyczne wysiłki zapanowania nad tym konfliktem, konieczne okazało się odwołanie do użycia siły. UE nie była w stanie tego uczynić, ponieważ nie dysponowała własnym potencjałem w tej dziedzinie. Jedynym instrumentem tego rodzaju był nadal Sojusz Północnoatlantycki, który pod względem decyzyjności i zdolności wojskowych został niemal zawłaszczony przez Stany Zjednoczone. Administracja Billa Clintona po doświadczeniu somalijskim zakończonym fiaskiem długo opierała się europejskim (zwłaszcza Francji i Wielkiej Brytanii) namowom militarnego zaangażowania w zatrzymanie wojny w Jugosławii. Kiedy jednak podjęto ostateczną decyzję o użyciu sił zbrojnych, dowództwo USA czyniło to bez oglądania się na partnerów z Europy. Przytaczając słowa R. Kuźniara „po całym zachodzie rozlał się lament, Europa nie zdała egzaminu, że potrafi 'tylko gadać', a gdy przychodzi 'co do czego', to tylko Stany Zjednoczone potrafią wziąć na siebie odpowiedzialność i tylko na nie można liczyć w sprawach europejskiego bezpieczeństwa" (Kuźniar, 2014: 33). Kolejnym trudnym doświadczeniem dla Unii Europejskiej był kryzys w Kosowie i interwencja NATO przeciwko Federalnej Republice Jugosławii wiosną 1999 r. Wprawdzie większość państw UE poparła tę interwencję, lecz jej strategię narzuciły ponownie Stany Zjednoczone, które stosując zasadę ,zero strat własnych” (czyli ograniczenie się do ataków z powietrza, które w początkowej fazie przyczyniły się tylko do eskalacji konfliktu), doprowadziły również do zhańbienia interwencji humanitarnej. Ponadto, interwencja nie miała autoryzacji Rady Bezpieczeństwa ONZ, a były prezydent USA Bill Clinton został posądzony o dowodzenie armią z pola golfowego. Niezależnie od oceny przebiegu i skutków tej operacji, Unii Europejskiej ponownie zarzucono w sprawach bezpieczeństwa na kontynencie bezpośrednią zależność od USA.

Europejskie aspiracje do rozwoju potencjału Wspólnej Polityki Bezpieczeństwa i Obrony zakłóciła seria wydarzeń różnej natury, która miała jednak wspólną płaszczyznę, niedojrzałość oraz niechęć państw Unii Europejskiej, przede wszystkim jej mocarstw, do odgrywania przez nią mocarstwowej roli. Czołowe państwa zajmowały w kolejnych latach w różnych sytuacjach i dziedzinach odmienne stanowiska, a ich unilateralizm oraz partykularne interesy ostatecznie zaprzepaściły projekt Unii, jako wiarygodnego partnera, a co za tym idzie uczyniły mało istotnym jej wspólną strategię 
bezpieczeństwa. To się zaczęło już w związku z wojną USA przeciwko Irakowi. Kryzys iracki nie tylko skutecznie podzielił Unię. Nawet Polsce zarzucono rolę „konia trojańskiego". Część jej członków podjęła nawet pogardliwy ton wobec mocarstwowych ambicji Europy, i przyjęła z D. Rumsfeldem i R. Kaganem optykę podziału Zachodu na dzielnych kowbojów czy myśliwych zdobywających pożywienie oraz tchórzliwych i leniwych kelnerów zadowalających się zmywaniem naczyń (w nieco wznioślejszym wydaniu - na tych z Marsa i tych z Wenus) (ibidem: 39). Ten podział był tym głębszy, że dokonał się wbrew zasadom wspólnej polityki zagranicznej i bezpieczeństwa oraz wbrew wyraźnie zajętemu tylko nieco wcześniej stanowisku państw członkowskich, które zakładało trzymanie się postanowień odpowiedniej rezolucji RB NZ. Problem z lojalnością wobec Europy miały nie tylko państwa „nowej Unii”, z Polską na czele, ale też państwa „starej Unii” z Wielką Brytanią i Hiszpanią. Polskie władze krótko korzystały z glorii „,nowej Europy” (dynamicznej, odważnej, przyszłościowej) patrzącej z góry na „starą Europę” - dekadencka, rentierską (ibidem: 41). Podsumowując, akcja przeciw Irakowi okazała się w pełni nieuzasadniona ze względu na brak dowodów posiadania broni chemicznej przez Saddama Husajna, a także kolejną porażką dla Stanów Zjednoczonych. Konflikt iracki pokazał łatwość, z jaką poszczególne państwa zdecydowały się działać unilateralnie, nie patrząc na interesy i stanowisko całej UE, a tylko mając na względzie własne, partykularne, dyktowane zewnętrznymi okolicznościami korzyści.

W obliczu nowych zagrożeń współpraca NATO z Unią Europejską, która powinna posiadać odpowiedni potencjał militarny jest konieczna, aby działać skuteczniej i efektywniej. Zamierzenie to jednak nie jest podzielane przez wszystkie państwa Sojuszu. Jednym $z$ efektownych wizerunków tego poglądu było pominięcie przez członkowskie mocarstwa w kontekście ich interwencji w Libii w 2011 r. Można uznać, że sytuacja, która miała miejsce w tym kraju w związku z arabską wiosną była na miarę aspiracji UE, zapisanych $\mathrm{w}$ traktacie $\mathrm{z}$ Lizbony mandatowi WPBiO oraz już osiagnniętym zdolnościom wojskowym Unii. Jednak Francja i Wielka Brytania dokonujące tam interwencji, z inicjatywy dążącego do reelekcji prezydenta N. Sarkozy'ego, postanowiły wyjść poza mandat udzielony rezolucją RB ONZ i obalić rządy M. Kadafiego. Państwa te uznały przy tym, że do takiej operacji potrzebują NATO (czyli USA). Trywializując, można powiedzieć: „operacja się udała, pacjent umarl” (ibidem: 43). W rezultacie tej interwencji i obalenia M. Kadafiego Libia stała się państwem upadłym, a jej rozkład sprzyjał i nadal sprzyja rozwojowi ruchów rebelianckich i terrorystycznych takich jak Państwo Islamskie. Ponadto, przez otwartą Libię ruszyła do Europy niekontrolowana fala afrykańskich imigrantów, w tym uchodźców. Hipotetycznie, można byłoby uniknąć wszystkich wynikłych nieporozumień i nieszczęść, gdyby operacja przeprowadzona była zgodnie z mandatem RB ONZ przez Unię Europejską.

W swojej Wspólnej polityce zagranicznej, bezpieczeństwa i obrony niezależnie od tego, jaka ona jest, Unia Europejska woli zajmować się problemami Afryki czy Iraku niż Europy Wschodniej. Znamienne jest, że kilka mocarstw i państw europejskich bez wahania zaangażowało się w walkę przeciwko Państwu Islamskiemu, zarówno bezpośrednio biorąc udział w lotniczych misjach bojowych, jak i pośrednio, np. przez dostawy broni. Żadne państwo, z obawy przed reakcją Rosji, nie zdecydowało się jednak na dostawy broni dla będącej przedmiotem rosyjskiej agresji Ukrainy. Wszystkie państwa są ostrożne przed podjęciem tak poważnego działania, niemniej jednak wciąż 
toczą się rozmowy o rozważeniu takiej decyzji. Po raz kolejny uwidacznia się w tym nie tylko zanik geopolitycznego instynktu UE, ale gotowość do podejmowania jedynie bezpiecznych, bez większej odpowiedzialności operacji, z dala od granic Europy, nie zaś konkretnych działań ku podnoszeniu bezpieczeństwa europejskiego. W chwili obecnej musimy się zadowolić Unią Europejska, jako wspólnotą bezpieczeństwa, która dysponuje jedynie „miękkimi” środkami, zapewniając bezpieczeństwo wewnątrz jej samej. Niejednokrotnie nie docenia się tej wartości Unii oraz iście zrewolucjonizowanego przewrotu, który wniosła do stosunków międzynarodowych na starym kontynencie. Aktualnie nawet to zaczyna być kontestowane przez siły, także w Polsce, które chcą dekompozycji UE, nie przewidując związanych z tym konsekwencji. Przed zwolennikami Unii, jako „twardego” systemu bezpieczeństwa jeszcze długa droga, ale wszyscy, którzy przyjrzeli się bliżej temu trendowi wiedza, że nie wolno tego zaniechać.

\section{OGRANICZENIA WPBiO}

Na polityczno-instytucjonalne ograniczenia WPBiO już po traktacie lizbońskim trafnie wskazuje jeden z najlepszych jej znawców, dyrektor Instytutu Bezpieczeństwa UE, Nicole Gnesotto. Jej zdaniem, także po tym traktacie „polityka bezpieczeństwa i obrony Unii pozostaje w dalszym ciagu polityką zarządzania kryzysami innych. $\mathrm{W}$ sprawach prawdziwej polityki bezpieczeństwa i obrony, jak celnie zauważa N. Gnesotto, zgodnie z traktatem prymat zachowuje NATO (dla członków tego sojuszu) oraz kompetencje i odpowiedzialność samych państw członkowskich. Nawet, jeśli traktat zawiera klauzulę elastyczności dopuszczającą współpracę strukturalną - pogłębioną w sferze obrony dla mniejszej grupy państw, to byłoby to ćwiczenie w rodzaju sztuki dla sztuki, bowiem każda operacja wojskowa UE (tej grupy państw) może się odbyć jedynie za zgodą wszystkich jej członków (Gnesotto, 2012: 58-61). W ten sposób Unia Europejska mogła się specjalizować w niewielkich i nawet pożytecznych operacjach wojskowych, cywilno-wojskowych czy policyjnych, które, choć kosztowne, nie miały najmniejszego znaczenia dla jej roli międzynarodowej (Ciupiński, 2013). Ponadto większość państw członkowskich UE nie przejawia zbytnich chęci do użycia swoich pododdziałów do operacji w ramach WPBiO. Istnieje prawdopodobieństwo, że w przypadku poważnego kryzysu w bliskim sąsiedztwie UE, niesprawdzone grupy mogłyby sobie nie poradzić z tak dużym wyzwaniem, głównie z powodu braku wspólnych ćwiczeń zgrywających poszczególne komponenty narodowe. Operacje, w jakie mogłyby być zaangażowane dla przykładu unijne grupy bojowe, nie wpływają bezpośrednio na poziom bezpieczeństwa państw wydzielających siły, ale generują znaczne koszty, i to zarówno finansowe, jak i polityczne. $\mathrm{Z}$ tego powodu część państw członkowskich (m.in. Niemcy, Holandia) uznaje użycie grup bojowych w tego typu operacjach oraz ich regularne wykorzystywanie na potrzeby typowych operacji WPBiO za nieuzasadnione, podkreślając, iż powinny one stanowić narzędzie szybkiej reakcji UE jedynie w razie najpoważniejszych kryzysów. Znaczenie mają także wysokie koszty takiego zaangażowania (Trelikowski, 2010).

Przejawem wymierania zdolności UE do postrzegania swej polityki bezpieczeństwa i obrony, jako instrumentu budowy strategicznego wymiaru jej tożsamości mię- 
dzynarodowej (zgodnie z traktatem z Maastricht) była niechęć i niemożność podjęcia prac na rzecz zdefiniowania nowej strategii bezpieczeństwa. Stara strategia z $2003 \mathrm{r}$. jest już nieaktualna ze względu na dynamicznie rozwijająca się sytuację geopolityczną i aż prosi się o jej nowelizację. Zmiany w środowisku międzynarodowym również uzasadniały taką potrzebę aż nadto. Nie była tym zainteresowana ani C. Ashton, ani duże państwa członkowskie. Mimo presji ze strony takich państw jak Polska, Unii Europejskiej udało się uniknąć tego ćwiczenia w okolicy dziesiątej rocznicy przyjęcia pierwszej i jedynej ESB. W to miejsce problematyka WPBiO stała się po raz pierwszy od wielu lat przedmiotem posiedzenia Rady Europejskiej w grudniu 2013 r. Mimo że początkowo miało to być specjalne posiedzenie poświęcone tylko WPBiO, unijni przywódcy więcej czasu przeznaczyli na sprawy unii bankowej, niż na sprawy związane stricte z bezpieczeństwem. Przyjęto wiele pożytecznych, lecz technicznych decyzji, a do problemu ewentualnej rewitalizacji polityki bezpieczeństwa i obrony postanowiono wrócić w 2015 r. Oceniając z dłużej perspektywy rozwój Wspólnej Polityki Bezpieczeństwa i Obrony należy uznać, że potrzebuje ona realnego strategicznego drogowskazu. Unia Europejska doświadczyła już gorzkich lekcji, że odwlekanie podjęcia wyzwania uzgodnienia fundamentalnych kwestii przynosi w dłuższej perspektywie poważne problemy. W tym kontekście planowany na czerwiec 2015 r. szczyt Rady Europejskiej powinien w jednej ze swych konkluzji postawić zadania opracowania nowej strategii bezpieczeństwa Unii Europejskiej.

Jednocześnie daje się zauważyć, że Stany Zjednoczone ze względu na przeniesienie swojego środka ciężkości do Azji, w mniejszym stopniu chcą się angażować w działania, co do których uważają że UE powinna sama sobie poradzić (np. w Libii w 2011 r.). Konieczne wydaje się, zatem zwiększenie zaangażowania Unii w sprawy międzynarodowe oraz wzięcie za nie większej odpowiedzialności. Wciąż większość państw w Unii Europejskiej przeznacza zbyt mało środków na swoją obronność, nie przekraczając $1,8 \%$ PKB powiększając przez to lukę technologiczną która wpływa na małą kompatybilność i ograniczoną możliwość współpracy z NATO. Niezbędne jest utworzenie sił zbrojnych, które będą pozostawały w dyspozycji Unii Europejskiej jako organizacji. Funkcjonowanie grup bojowych w obecnym modelu nie sprawdziło się. Aby sprostać współczesnym wyzwaniom należy przełamać w końcu ten impas, bo środowisko bezpieczeństwa wymaga teraz skoordynowanych i dużo bardziej efektywnych działań NATO i UE. Takim motorem napędowym współpracy powinna być z naszej perspektywy przede wszystkim Ukraina. Należy jednak pamiętać, że dla wielu innych państw będzie to zagrożenie ze strony Państwa Islamskiego operującego już nie tylko na Bliskim Wschodzie i Afryce, ale przenoszącego się powoli również do Europy (zjawisko blowback). Ze względu na to, że kryzysy w mniejszym lub większym stopniu dotyczą wszystkich członków UE i NATO, można to umiejętnie wykorzystać do zacieśnienia współpracy.

\section{WIZJE NOWEGO SEKRETARZA OBRONY NATO}

1 października 2014 r. były premier Norwegii Jens Stoltenberg zastapił na stanowisku szefa NATO Duńczyka Andersa Fogha Rasmussena. Po raz pierwszy sekretarzem generalnym Sojuszu został polityk kraju nienależącego do Unii Europejskiej. 
Jednym z czynników, który przesądził o nominacji dla J. Stoltenberga, mógł być fakt, że dla NATO region północny i bałtycki w związku z napiętą sytuacją z Rosją w najbliższym czasie będzie miał szczególne znaczenie. Wybór Norwega jest jednocześnie wyrazem uznania dla roli tego kraju w Sojuszu. Norwegia jest jednym z niewielu, gdzie wydatki na obronę rosną. Ponadto jest aktywna w operacjach wojskowych. Jens Stoltenberg uważany jest za zwolennika misji prowadzonych pod auspicjami NATO, jak również tych prowadzonych przez Stany Zjednoczone. Poparł on ogłoszoną przez prezydenta George'a Busha wojnę z terroryzmem, jak również decyzję o wysłaniu wojsk do Afganistanu czy bombardowaniach Libii przez NATO, co przyczyniło się do obalenia Muammara Kadafiego w 2011 r. Szef BBN Stanisław Koziej, komentując decyzję Rady Północnoatlantyckiej uważa, że nowy szef NATO, jako przedstawiciel państwa granicznego ,zna i rozumie specyfikę także takich państw jak Polska. Jest więc szansa, że nasze interesy oraz nasze postrzeganie wyzwań, potrzeb i zasad funkcjonowania NATO znajdzie dobrego adresata w przyszłym sekretarzu generalnym" (Soja, 2014).

Rosyjskie media, przy całej swojej niechęci do NATO, nie odniosły się negatywnie do nominacji dla Jensa Stoltenberga, który uchodzi za człowieka konsensusu i polityka, który jeszcze w okresie swojego premierostwa próbował budować pozytywne relacje z Rosją. J. Stoltenberg, w przeciwieństwie do swojego poprzednika, prezentuje bardziej elastyczne podejście w polityce wobec Rosji, zbudował także sprawnie funkcjonujące partnerstwo z prezydentem Władimirem Putinem (Koshkin, 2014). Nowy sekretarz generalny zapowiedział, że oczekuje konstruktywnych relacji z Federacją Rosyjska, nie wykluczył także wznowienia obrad Rady NATO-Rosja, które zostały zawieszone w kwietniu, po aneksji Krymu - niezgodnej z prawem międzynarodowym. Pomimo to J. Stoltenberg zają jednak zdecydowane stanowisko wobec Rosji, zarzucając jej łamanie prawa międzynarodowego oraz destabilizowanie sytuacji na Ukrainie.

Należy jednak zaznaczyć, że najważniejsza zapowiedź J. Stoltenberga dotyczyła wdrożenia postanowień szczytu NATO w Newport, w czasie którego zdecydowano m.in. o przyjęciu Planu na rzecz Gotowości do Działań (ang. Readiness Action Plan, RAP) i utworzeniu tzw. szpicy, która jest pierwszym wyraźnym krokiem świadczącym o wdrażaniu nowej strategii Sojuszu (NATO, 2014). Zmiany w strukturze bezpieczeństwa w Europie to część całego łańcucha wydarzeń w ostatnim czasie, które są niepomyślną informacją z punktu widzenia strategii Rosji wobec Europy Wschodniej. Szef NATO podkreślił, że są to największe zmiany w Europie od 25 lat.

Ministrowie spraw zagranicznych państw NATO uzgodnili, że tymczasowa szpica, czyli siły natychmiastowego reagowania, uzyskają zdolność operacyjną z początkiem 2016 r. Można ocenić, że będzie to struktura pośrednia, dzięki której przyspieszony zostanie proces budowania właściwej szpicy. Decyzja ta, mająca na celu zwiększenie możliwości szybkiej odpowiedzi na zagrożenia, kończy okres niepewności związanych z kwestią bezpośredniej obrony. Tymczasowa szpica będzie składać się z oddziałów z Niemiec, Holandii i Norwegii. Sekretarz generalny NATO zapowiedział jednak, że w przyszłym roku swój wkład do szpicy wniosą wszystkie z 28 państw należących do Sojuszu. Ostateczne decyzje co do właściwej szpicy, czyli jej składu, struktury i finansowania, zostaną podjęte podczas kolejnego spotkania w Monachium. Wiadomo, że jej liczebność ma wynosić 5 tysięcy żołnierzy, i że będzie składać się ona z komponentu lądowego, morskiego, powietrznego oraz wojsk specjalnych. 
Siłą przewodnią nowej grupy zadaniowej będą państwa europejskie, które posiadają najliczniejsze siły zbrojne, czyli Wielka Brytania, Niemcy i Francja. Jest to duży krok w celu odciążenia Stanów Zjednoczonych, które, jak dotąd, najmocniej zaangażowały się w strategię odstraszania Rosji w Europie wschodniej. Jest to dla nas bardzo dobry sygnał, który oznacza przejęcie przez UE większej odpowiedzialności za sprawy regionalne. Utworzenie tymczasowej szpicy oznacza, że ta właściwa osiagnie zdolność operacyjną już w przyszłym, a nie w 2016 roku, jak pierwotnie zakładano. Jak podkreślono, utworzenie szpicy jest najważniejsze dla Polski i państw bałtyckich, które obawiają się możliwości rosyjskiej interwencji zbrojnej, jeśli doszłoby do pogłębienia się konfliktu na Ukrainie. Według planu, szpica ma być gotowa do rozmieszczenia w strefach kryzysowych w ciagu 2-5 dni. Ma zostać wyodrębniona z utworzonych w 2003 r. Sit Odpowiedzi NATO (ang. NATO Response Force, NRF), liczących 13 tysięcy żołnierzy (Winning, 2014). Obecnie dowództwo nad całością sił NRF pełnią Niemcy, podczas gdy Polacy pod dowództwem gen. Guta kierują komponentem sił specjalnych działających w ramach tej formacji.

Podczas spotkania w Brukseli zapadła także decyzja o kontynuowaniu obecności zbrojnej NATO w 2015 r. w państwach znajdujących się na wschodniej flance Sojuszu (Croft, 2014). Działania te stanowią odpowiedź NATO na konflikt zbrojny na Ukrainie, agresywne działania Rosji w Europie wschodniej oraz rosnące zagrożenie ze strony organizacji terrorystycznych dla południowej części kontynentu. J. Stoltenberbg oświadczył, że jest to największe wzmocnienie dla kolektywnej obrony od czasu zakończenia Zimnej Wojny. Proces ten już się rozpoczął poprzez zwiększenie obecności wojskowej w państwach baltyckich, Polsce i Rumunii. Ogłoszenia szefa NATO o utworzeniu tymczasowej szpicy nadeszło w odpowiedniej chwili, jako że media coraz częściej informowały o kłopotach Sojuszu z wdrażaniem strategii z Newport. Podjęcie konkretnych kroków przez NATO jest ważne $z$ uwagi na przedłużający się konflikt na Ukrainie oraz otrzymujące się napięcie w relacjach z Rosją. Procesowi temu towarzyszą doniesienia o poważnych stratach, jakie rosyjska gospodarka ponosi wskutek nałożenia sankcji gospodarczych przez Unię Europejską i USA oraz informacje o zawieszeniu sprzedaży samolotów Mistral przez Francję. Państwa wschodniej flanki Sojuszu muszą teraz zdecydować, czy są gotowe do utworzenia na swoich terytoriach składów z NATO-wską bronią oraz, prawdopodobnie ośrodków przyjmujących dla żołnierzy państw Sojuszu. Ten łańcuch wydarzeń, którego przypieczętowaniem jest decyzja NATO w sprawie tymczasowej szpicy oznacza, że w Europie, a zwłaszcza w jej wschodniej części, ruszył proces wielkich zmian w architekturze bezpieczeństwa europejskiego opartej o zasoby NATO.

\section{ODPOWIEDŹ STANÓW ZJEDNOCZONYCH}

W najbliższej przyszłość należy oczekiwać także decyzji Pentagonu w sprawie możliwego zatrzymania procesu wycofywania sił zbrojnych USA z Europy, podległych dowództwu EUCOM, o co apelowali m.in. gen. naczelny dowódca sił NATO Philip Breedlove oraz dowódca Armii Stanów Zjednoczonych w Europie gen. Frederick Ben Hodges. Armia Stanów Zjednoczonych w Europie bada obecnie możliwości rozmieszczenia sprzętu wojskowego w Europie Środkowo-Wschodniej. Jak poinformował magazyn „Stars and Stripes” do państw bałtyckich, Polski, Rumunii i Bułgarii już wkrótce 
zostanie wysłany specjalny zespół, którego zadaniem będzie znalezienie miejsc dyslokacji sprzętu, w tym czołgów (Vandiver, 2015). Gen. Ben Hodges, dowódca USAREUR, w rozmowie ze „Stars and Stripes” podkreślił, że po dokonaniu oceny sytuacji sporządzone będą formalne zalecenia, które w przyszłym roku zostaną przedstawione gen. Philipowi Breddlove'owi, dowódcy sił NATO w Europie. Zgodnie z zapowiedzią gen. Hodgesa: „Chcemy umieścić część jednostek w Europie Południowo-Wschodniej, państwach bałtyckich i Polsce; te kraje potrzebują tego bardzo, co jest oczywiste, jako że stanowią element powstrzymywania" (Millham, 2014). Wojskowy wyraził również opinię, że w najbliższym czasie amerykańska obecność zbrojna będzie mieć charakter trwałej obecności wzdłuż wschodniej flanki NATO z udziałem sił ze Stanów Zjednoczonych. Jak dodał, kluczowym elementem tego planu mają być tzw. siły dostosowane regionalnie (ang. Regionally Aligned Forces, RAF). W rzeczywistości część tych sił jest już w Europie i bierze udział w ćwiczeniach, stanowiąc część środków zapewniania bezpieczeństwa i odstraszania. Ruch Armii Stanów Zjednoczonych w Europie jest zgodny z oceną wyrażoną przez Zbigniewa Brzezińskiego, doradcę ds. bezpieczeństwa narodowego prezydenta Jimmy'ego Cartera. Jego zdaniem, USA powinny wysłać żołnierzy do państw bałtyckich w ramach strategii odstraszania, ponieważ ich obecność mogłaby zapobiec potencjalnej inwazji ze strony Rosji. Serwis „Defensenews”, przytaczający rozmowę ze Zb. Brzezińskim wskazał, że wśród państw, które mogłyby wysłać swoich żołnierzy, oprócz USA, są także Niemcy, Francja i Wielka Brytania (Brzeziński, 2015).

Konflikt na Ukrainie doprowadził do pewnego przewartościowania w zakresie wielkości obecności zbrojnej USA w Europie. W listopadzie 2014 r. gen. Philip Breedlove wystapił $z$ apelem do Pentagonu o zatrzymanie procesu redukowania obecności wojskowej USA w Europie. Jak ocenił, presja ze strony Rosji sprawiła, że państwa bałtyckie, Polska i Rumunia potrzebują dodatkowej rotacyjnej obecności wojskowej. Pentagon zamierza przeprowadzić proces konsolidacji sił amerykańskich w Europie, co oznacza zamknięcie niektórych baz. Takie kroki niekoniecznie jednak muszą prowadzić do redukcji amerykańskiego potencjału wojskowego. Uwagę na to zwróciła Janine Davidson z Rady Stosunków Zagranicznych (CFR), przypominając, że gdy w 2012 r. z Europy wycofano dwie brygady bojowe, Pentagon zapewnił sojusznikom dodatkowy potencjał zbrojny w postaci obrony rakietowej i wojsk specjalnych. Ekspert z USA przypomniała jednak, że państwa europejskie muszą przeznaczać więcej środków finansowych na cele wojskowe, o co władze Stanów Zjednoczonych apelują w ostatnim okresie. Bez większego finansowania z ich strony plany NATO, dotyczące gotowości do działań, mogą pozostać jedynie na papierze. Kluczowe może tu być spotkanie w Monachium z udziałem ministrów obrony państw Sojuszu, którzy prawdopodobnie podejmą decyzje w sprawie kształtu właściwej szpicy. Najtrudniejszą sprawą będzie jednak jej finansowanie, choć kosztami powinny podzielić się wszystkie państwa NATO.

Zapowiedź o przesunięciu części sprzętu wojskowego do państw Europy Środkowo-Wschodniej będzie mieć duże znaczenie strategiczne, choć zajmie jeszcze co najmniej kilka miesięcy. Wysłanie zespołu, który ma zbadać sytuację na miejscu, jest jednak pierwszym krokiem służącym realnemu zabezpieczeniu flanki wschodniej Sojuszu. Pytaniem pozostaje rozmiar zasobów, jakie Pentagon będzie skłonny przeznaczyć na potrzeby odstraszania Rosji. Stany Zjednoczone nie ukrywają, że liczą także, iż 
europejscy sojusznicy już wkrótce zwiększą wydatki na cele wojskowe, zgodnie z oczekiwaniami, co do wdrażania planu działań na rzecz bezpieczeństwa europejskiego. Zwiększenie nakładów na cele wojskowe przez państwa europejskie byłoby zachętą dla USA do mocniejszego zaangażowania się we wschodniej części kontynentu, ponieważ byłoby dowodem dla władz amerykańskich, że Europejczycy poważniej traktują kwestie bezpieczeństwa. Zwiększenie takich wydatków jest logiczne w sytuacji, gdy wyzwaniem dla bezpieczeństwa Europy jest nie tylko sytuacja na Ukrainie, ale także zagrożenie ze strony islamskich organizacji terrorystycznych. Europejczycy zdają sobie sprawę z konieczności inwestowania we własne zdolności wojskowe, co również potwierdzają konkluzje Rady Europejskiej z grudnia 2013 r. (Rada Europejska, 2013). Rozwój zdolności i przemysłu obronnego powinny być wyrazem nowej odpowiedzialności UE za swoje własne bezpieczeństwo, czego od dawna domagają się od Europy jej amerykańscy sojusznicy. Popyt na europejskie zdolności obronne wzrośnie, bez względu na to, czy będą one wykorzystywane pod dowództwem europejskim, NATO czy narodowym. Unia Europejska nie może już dłużej pomijać tej kwestii. Brak solidarności w tej sprawie doprowadziłby w dłuższej perspektywie do osłabienia NATO oraz jego gwarancji dla państw członkowskich.

$$
* * *
$$

Napięta sytuacja w 2014 r. stanowi największe wyzwanie dla NATO oraz Unii Europejskiej od czasów zakończenia Zimnej Wojny. Sojusz rozpoczął proces adaptacji do zmian, ale najważniejszą kwestią jest teraz realizacja, zapowiedzi, które padły z ust polityków i wojskowych. Rosja, nawet osłabiona przez kryzys gospodarczy, pozostaje liczącą się potęga w sensie militarnym, a nic, jak na razie, nie zapowiada zdecydowanego zwrotu w polityce Federacji Rosyjskiej. Przed zdaniem swoich obowiązków mówił o tym w swoim wystapieniu szef NATO Anders Fogh Rasmussen, który ostrzegł, że „Ukraina jest jedynie częścią wielkiego planu Władimira Putina” (Hellewig, 2014). NATO oraz Unia Europejska nie może zatrzymać się w połowie drogi, natomiast powinna w pełni wdrożyć ustalenia z Newport. Twarda polityka już nie raz pokazała, że nie toleruje pustych deklaracji. Paradoksalnie, niespokojny rok 2014, był korzystny z punktu widzenia interesów Polski, choć zagrożenie wojskowe osiagnęło najwyższy poziom w historii ostatniego ćwierćwiecza. Polska powinna pozostać jednak aktywnym graczem na forum NATO, a także UE, jeśli chce, by finał prac nad nową architekturą bezpieczeństwa w Europie przyniósł rezultaty zgodne z polskimi interesami. Ostatnie wydarzenia w Europie wschodniej, przywołały bowiem obawy związane z doświadczeniami historycznymi Polski, a zwłaszcza z tragicznym rokiem 1939. Jeśli państwa europejskie chcą uniknąć powtórki tego czarnego scenariusza, muszą skłonić NATO do szybkiego reagowania w odpowiedzi na pojawiające się zagrożenia. Jest to szczególnie ważne, bo za sprawą polityki Rosji, po raz kolejny mamy do czynienia z próbą podzielenia Europy na strefę wpływów Zachodu i strefę wpływów Rosji. Pomimo to, tak wielkiej szansy na współdecydowanie o kształcie bezpieczeństwa kontynentu, jak teraz, jeszcze nie mieliśmy. Najważniejsze jest, by tej historycznej szansy nie zmarnować, choć już teraz wiadomo, że Polskę i Europę czekają bardzo trudne lata. 


\section{Bibliografia}

Blair D. (2014), Jens Stoltenberg: the new man at Nato who must stand up to Putin and his tanks, „The Telegraph”, http://www.telegraph.co.uk/news/worldnews/europe/russia/11233199/Jens-Stoltenberg-the-new-man-at-Nato-who-must-stand-up-to-Putin-and-his-tan (15.11.2014).

Brzeziński Z. (2015), US Should Deploy Troops to Baltics, „Defence News”, http://www.defensenews.com/story/defense-news/2015/01/21/us-deploy-troops-baltics/22123409 (21.01.2015).

Ciupiński A. (2013), Wspólna Polityka Bezpieczeństwa i Obrony Unii Europejskiej. Geneza - rozwój - funkcjonowanie, Warszawa.

Croft A. (2014), NATO to create new 'spearhead'force to respond to crises, Reuters, http://www.reuters.com/article/2014/09/01/us-ukraine-crisis-nato-military-idUSKBN0GW2SP20140901 (1.09.2014).

Deklaracja końcowa szczytu NATO w Walii (2014), http://www.bbn.gov.pl/pl/wydarzenia/6170,Deklaracja-koncowa-szczytu-NATO-w-Walii-z-2014-r-polskie-tlumaczenie.html (5.09.2014).

Dyplomacja czy siła? Unia Europejska w stosunkach międzynarodowych (2009), (red.) S. Parzymies, Warszawa.

Rada Europejska - Konkluzje (2013), 19-20.12.2013, http://www.consilium.europa.eu/uedocs/ cms_data/docs/pressdata/PL/ec/140261.pdf (7.10.2014).

Europejska Strategia Bezpieczeństwa (2003), https://www.consilium.europa.eu/uedocs/cmsUpload/ 031208ESSIIPL.pdf (15.10.2014).

Gnesotto N. (2012), Przyszłość Europy strategicznej, Warszawa.

Gocuł M. (2015), Sojusz Gwarantem stabilizacji, „Przegląd Sił zbrojnych”, nr 1.

Gościnny Malbork - kolejna zmiana sojuszników (2015), Dowództwo Generalne Rodzajów Sił Zbrojnych, Inspektorat Sił Powietrznych, Warszawa.

Koshkin P. (2014), Will NATO'S New Head lead to new thinking about Russia?, „Russia Direct”, http://www.russia-direct.org/debates/will-natos-new-head-lead-new-thinking-about-russia (9.10.2014).

Koziej S. (2014), O potrzebie nowej strategii bezpieczeństwa Unii Europejskiej, „Bezpieczeństwo Narodowe", nr IV/32.

Kuźniar R. (2014), Wzlot i upadek Europejskiej Polityki Bezpieczeństwa i Obrony, „Bezpieczeństwo Narodowe", nr IV.

Milczarek D. (2003), Pozycja i rola Unii Europejskiej w stosunkach międzynarodowych, Warszawa.

News release No: NR-260-14 (2014), U.S. Department of Defense, Department Announces Facilities Adjustments in Europe, 23.05.2014.

Pietrzak P. (2012), Szczyt NATO w Chicago - determinanty, oczekiwania i rezultaty, „Bezpieczeństwo Narodowe", nr II/22.

Soja M. (2014), Fundacja Dyplomacja i Polityka, [online], Nowy Szef NATO, http://www.dyplomacja.org/index.php/pl/osmsz/83-omsz/229-nowy-szef-nato.html (7.10.2014).

Terlikowski M. (2010), Grupa bojowa Unii Europejskiej pod Polskim dowództwem, „Biuletyn. Polski Instytut Spraw Międzynarodowych", 11.01.2010.

Wales Summit Declarations Issued by the Heads of State and Government participating in the meeting of the North Atlantic Council in Wales (2014), NATO, http://www.nato.int/cps/en/natohq/official_texts_112964.htm (5.09.2014).

Winning A. (2015), At least 4,000 troops: NATO approves new Europe-based sperhed force, $\mathrm{http}: / / \mathrm{rt} . c 0 m /$ news/185444-nato-rasmussen-spearhead-force/ (5.09.2014). 
Vademecum NATO (2007), Brussels: NATO Office of Inform and Press, http://www.zbigniewgroszek.pl.pl/index_htm_files/NATO_vadem.pdf (10.10.2014).

Vandiver J. (2015), Army looking to store tanks, equipment in eastern Europe, „Stars and Stripes”, $\mathrm{http} / /$ www.stripes.com/army-looking-to-store-tanks-equipment-in-eastern-europe-1.325693 (25.01.2015).

Zięba R. (2012), Polska we Wspólnej Polityce Bezpieczeństwa i Obrony Unii Europejskiej, „Polityka i Społeczeństwo", nr 10.

\title{
STRESZCZENIE
}

Celem artykułu było przedstawienie możliwych obszarów współpracy Sojuszu Północnoatlantyckiego z Unią Europejską wobec obecnych oraz przyszłych zagrożeń. Niejednokrotnie partnerstwo Euroatlantyckie ucieleśnione w Sojuszu Północnoatlantyckim, służy Europejczykom za usprawiedliwienie dla ich ucieczki od strategicznej odpowiedzialności i delegowania na Stany Zjednoczone trwałego zarządzania regionalnym bezpieczeństwem, czy światową stabilnością. WPBiO jest narzędziem cywilno-wojskowym polityki zagranicznej Unii Europejskiej. Podobnie jak NATO musi pozostać narzędziem militarnej solidarności Stanów Zjednoczonych i Europy. Konflikt rosyjsko-ukraiński oraz ataki terrorystyczne w Europie i na świecie stały się wielkim sprawdzianem dla systemu bezpieczeństwa na obszarze Euroatlantyckim oraz wielką szansą na zacieśnienie stosunków pomiędzy Unią Europejską a NATO. Obecna sytuacja pokazuje, że Sojusz Północnoatlantycki oraz Unia Europejska nie mogą bagatelizować aktualnych zagrożeń. Powinny natomiast konsekwentnie realizować wspólne ustalenia, stosując „twardą politykę" wobec ekspansji Rosji oraz Państwa Islamskiego. Pojęcie Euroatlantycki interes narodowy z punktu widzenia retoryki jest niewatpliwie oksymoronem. Z punktu widzenia polityki określa jednak sprawę pilną i absolutnie konieczną zarówno dla państw członkowskich Sojuszu, jak i dla samej Unii Europejskiej.

\section{COOPERATION OF THE NORTH ATLANTIC ALLIANCE AND EUROPEAN UNION IN THE FACE OF CURRENT AND FUTURE THREATS}

\begin{abstract}
The purpose of the article was to present the possible areas of cooperation the North Atlantic Alliance and the European Union to the current or future threats. The Euro-Atlantic Partnership often embodied in the North Atlantic Alliance, serves Europeans as an alibi for their escape from a strategic responsibility and delegation to the United States sustainable management of regional security and global stability. CSDP is a tool for civil-military foreign policy of the European Union. Like NATO must remain a tool of the United States military solidarity and Europe. Russian-Ukrainian conflict and terrorist attacks in Europe and the world has become a big test for the security system on the Euro-Atlantic area and a great opportunity for the strengthening of relations between the European Union and NATO. The current situation shows that NATO and the European Union cannot underestimate the current threats. By contrast, they should consistently implement joint arrangements with a tough policy towards Russia and the expansion of the Islamic State. The concept of „Euro-Atlantic national interest” from the point of view of rhetoric is clearly an oxymoron. From a policy perspective, however, a matter of urgency sets and absolutely necessary for both the Allies and the European Union itself.
\end{abstract}

